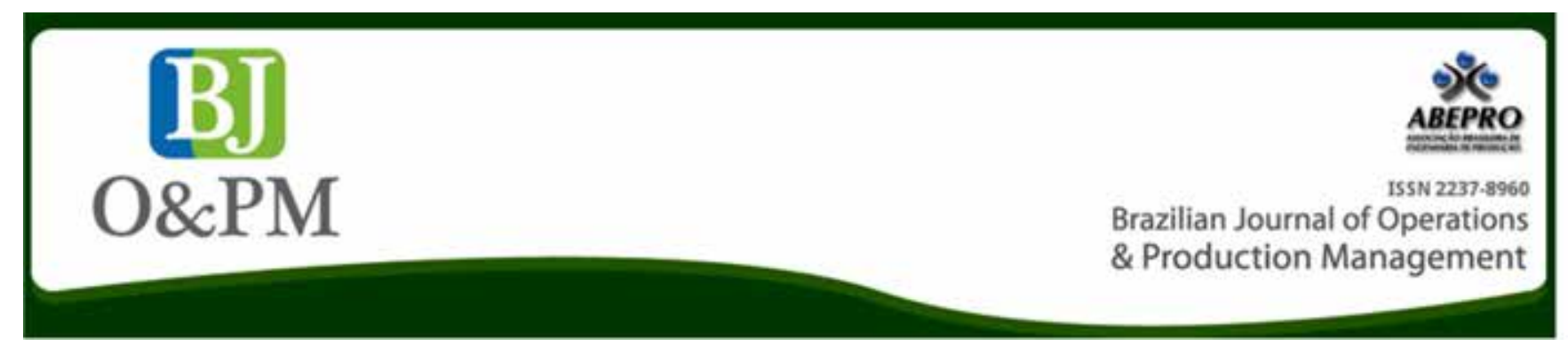

\title{
SOCIAL AND COLLABORATIVE BUSINESSES: APPROACHES AND POTENTIAL BROUGHT BY THE CREATIVE ECONOMY
}

\section{Clarisse Stephan}

clarisse.stephan@gmail.com Fluminense Federal University UFF, Niterói, Rio de Janeiro, Brazil.

\begin{abstract}
This paper aims at comprehending the new productive arrangements called social and collaborative business - drawing a parallel between them - and analyzing their potential for success in the market segment that has been called "Creative Economy". Upon the analysis of such economy, which is characterized for being intensive in immaterial goods (ubiquitous and non-rival), these new productive formats could take root, since, taking into account their propagated democratization ethics, self-management and sharing, their production factors should be, by excellence, not scarce and subject to continuous renewal.
\end{abstract}

Keywords: Social Business; Collaborative Business; Creative Economy. 
Brazilian Journal of Operations \& Production Management

Volume 15, Número 3, 2018, pp. 453-460

DOI: 10.14488/BJOPM.2018.v15.n3.a13

\section{INTRODUCTION}

(...) We are getting

free of property, which we are replacing by

use.

Starting with ideas. Which ones can we take? Which ones can we give?

(John Cage, 1965)

Social Business corresponds to a specific category of enterprises that was created by Muhammed Yunus ${ }^{1}$, in mid-1970's, drawing upon his experiences in newly independent Bangladesh. According to Yunus (2010), a social business is a new kind of undertaking that differs from traditional forms of corporate organization that seeks, as a primary purpose, the maximization of their profits. Yunus describes two kinds of social businesses, two forms of organization or management that would thereby be able to distinguish a "pure" social business from the other usages that the term "social" may currently assume. In accordance with its creator, there are two basic kinds of social business.

Social business of kind I is described as a company "with balanced revenues and costs, without any losses nor dividends, that is dedicated to solving a social problem. Their owners are investors that integrally reinvest profits in the expansion and enhancement of the business" (Yunus, 2010, p. 20). In this kind of business, investors could define the moment in which they would withdraw the invested amount; however, regardless of the moment of such withdraw, the latter would not be applied in any kind of correction, not even in an "index for neutralizing inflation": the withdrawn amount would always be the same as the one that had been invested at any time.

On its turn, social business of kind II would have the look of a company, under the classic models of dividends distribution; in other terms, it would be a company for profit, owned by poor people, constituted "either directly or through a fund destined to a predetermined social cause" ${ }^{2}$. As profits would be distributed among these

1 Muhammed Yunus is a professor and economist from Bangladesh who founded, in 1976, the Grameen Bank, "Village Bank", also known as the "Poor's Bank", a model institution for microfinance offer. Grameen Bank grant roughly BRL 5 billion on an annual basis to approximately 8 million people, $97 \%$ of whom are women (Yunus, 2017). Muhammed Yunus was the Nobel Peace Prize laureate in 2006.

2 "However, as individual property implies complicated legal issues in the sphere of the existing legal system, a way to provide poor people or a specific group of disfavored people all the benefits of company for profit is to grant its property to a fund that transfers such benefits to a target group". Yunus further explains people, "such company is, by definition, helping to solve a social problem. Grameen Bank belongs to the poor people that are their depositors and customers and is an example of this kind of social business" (Yunus, 2010, p. 20).

Thus, a social business, as proposed by Yunus, would enable the maximization of social benefits. In his view, capitalism failures, commonly referred to as market failures, are conceptual failures over the way in which human beings and their needs are stared at: as a rule, the mistake would be in limiting human desires and aspirations within an exclusively economic sphere; in limiting, therefore, man as a homo economicus. Still, according to him, the essential fact about humans is their multidimensionality. "Social business" appears as an alternative to typical corporate organizations, given that they have different goals from the latter, whose main objective lies upon profits maximization. A social business, despite being able to adopt a typical corporate model, has, as its main goals, the resolution or mitigation, in a given place, of a problem such as poverty, unemployment of environmental degradation. Work and its organization are understood as a way of intervening in local reality and shaping it to meet the needs of a community, generating positive externalities, either by the introduction of a new method of production that is less polluting, or by the creation of jobs destined to people in the fringe of the formal labor market. The accounting results of the company are important for its sustainability, but this is mainly anchored on social and environmental cornerstones.

On the other hand, collaborative businesses are frequently defined solely as "commercial practices" that give feasibility to the flow and access to goods and services among suppliers, donors, investors and employees/ consumers, where monetary exchanges between the involved parties do not necessarily take place. As a general rule, the interaction between such individuals occurs in a virtual environment (except for coworking physical spaces) and the idea of collaboration and cooperation is their dominant ethics. In crowdfunding and crowdsourcing websites, which are the most common practices of this kind of business, the maximization of profits does not constitute their main objective either; however, the own production of goods or services, made available therein as ideas, enabling the "public" to access them (what already represents, in a certain way, a breach within the ownership system in which intellectual property is embedded) and deliberate about their development through collective financing - that is, in principle, more democratic than the state instances for fostering "innovation", since they

that, in business of kind II, "the efficacy of the organization and its capacity to produce social benefits for the poor shall depend, to a great extent, on the talent and integrity of the members of the board of directors". 
grant access to the participation of a greater number of people to the instances of deliberation over which goods should be produced. Even though such structures of organization are not always constituted as companies, they do not dismiss some kind of institutionalization.

\section{SOCIAL AND COLLABORATIVE BUSINESS: APPROACHES}

The organization proposed by social and collaborative business brings them closer, as it enables an organization arrangement that reduces transaction costs (Coase, 1937), encouraging the compliance with contracts due to the celebration of relationships rooted on proximity and confidence, and that are directly influenced by competition and risks arising from asymmetric information, besides being an important mechanism for technological development.

Ideologically, the approach between the two kinds of business is due to their intern structure that is founded on collective decision-making processes and on a good relationship with the external public, which translates into concerns with their surroundings and with the environment. In the case of social business and likewise structures, which are grounded on the Solidarity Economy, frequently there is a management distribution (considering that vote, in quotaholders meetings, takes place per capita) of the undertaking's risks and of the unsubscribed shares; in the case of coworking spaces - another modality of collaborative organization - for example, the extent of such division necessarily comes about in cases of losses bore by the individuals who share a space, in a clear distribution of liabilities, even if each company or entrepreneur earns different values from the exploration of their business. In this sense, social and collaborative business are an important tool for technology (social included) experimentation and for the production of goods and services. It is a fact that collaborative economy may work as an important framework for social business, particularly under the crowdfunding and equity crowdfunding arrangements (taking into account, especially, social business of kind II, which foresee the possibility of distributing dividend among investors).

By granting priority to a Volvist ${ }^{3}$ decentralized organi-

3 In the 1970's, Volvo, a Swedish automobile manufacturer, started the implementation of a productive model with a post-toyotist inspiration. Resulting from the advancement in social-democrats policies in the country, such as the ones which claimed for equity of wages for workers, regional development, environmental protection, price control and wealth tax, Volvism responded to a political empowerment of workers through a zation, based on new technologies or in social technologies, we understand that there is a sense of proximity between social and collaborative business, although evidently not even every collaborative business can also be deemed as social. It is possible to affirm, at least theoretically, that the way of working proposed by the so-called Volvist mode of production would put emphasis on a conceptual and reflexive knowledge, stepping aside from the mere technical execution and, therefore, closer to the old medieval guild.

Castells (2013) affirms that the practices of industrial management from the 80 's have introduced another form of flexibility: the dynamic flexibility of the flexible production in large scale, allowing scale economies, and tailored and reprogrammable systems of production, what is mainly bind to new technologies, "which enable the transformation of typical assembling lines of big companies into production unities easily programmable that may meet market variations (product flexibility) and technological changes (process flexibility)" (Castells, 2013, p. 212).

The experience from the Italian northeast, with their industrial districts, is especially illustrative for this purpose: the technical qualification of human resources happens within the company, under qualification arrangements called learning by doing and bench-marking, in which several people involved in those processes work in teams, without predefined roles. Hence, there is a stimulus to the daily enhancement of their own capabilities and, consequently, the risk of marginalization whether there is no engagement and involvement in the social game of capabilities' valuation (Gurissati, 1999).

Sennet (2013) teaches us that corporations were successful thanks to the cooperation that they have shared with community - stakeholders in general, but especially their workforce - an alliance between detecting and solving problems. Sennet appraises, however, that such arrangement dodges a strict context of competition, that is so beloved of and deep-seated to corporate ethics ${ }^{4}$. He further explains that, in the competition realm, predefined patterns for the performance and conclusion of

concern, within the factory environment, regarding the quality of life and of the work performed by them (Nunes et al., 2009).

4 Under the Volvist mode of production, and even before, under Toyotism, the hierarchical principal is to rebuilt: teams are not only composed by the companies' personnel, existing a great collaboration of external members for specific projects and members of the same team do not necessarily work at the same venue, given the technological innovations. Work takes place in network and the companies' boundaries become more fluid, with contractual binds of shorter duration. 
Brazilian Journal of Operations \& Production Management

Volume 15, Número 3, 2018, pp. 453-460

DOI: 10.14488/BJOPM.2018.v15.n3.a13 tasks may be needed, in order to better direct the distribution of rewards, what would collide with an environment in which several people share functions and responsibilities.

This relates to the shrinkage of companies and to the organization in networks, with plenty of participants to work for projects. A dried company, interconnected to others through a network is the arrangement of the "modern company". Nevertheless, it is necessary to pay attention to the romanticized ideal suggested by the modern company, since especially in peripheral capitalist countries, the paradoxes brought by the "great" corporate organization have appeared to be highly accented ${ }^{5}$. A relevant point is that, by adopting their emergence as a starting point, Toyotism would be subject to the same contradictions of the system that inspired them: organizations themselves were changed so as to respond to the environment; thus, the idea of organization as an organism, so dear to the comprehension of that productive system - in opposition to the mechanism that Fordism is associated with - could constitute a challenge to its maintenance, given that flexibility would be its basis. The suggested adaptability would thereby be able to "catalyze the internal contradictions of the pyramid, undermining it from the inside. Simultaneously, this same set of factors would act upon the means, weakening the capacity of adaptation and the flexibility of the system" (Wood Junior, 1992, p. 15).

5 "The reasons that have been alleged in order to justify this anti-hierarchical burden most of the times are of a moral order and are part of a greater refusal to the dominant-dominated relationships (...). The general uplift in the educational level explains, for others, why hierarchy has become an overcome form of organization (Boltanski et Chiapello, 2009). What happens is that, according to Milton Santos: “(...) upon the industrial development, the number of qualified workers increases more rapidly than of the manual laborers, being the latter progressively substituted by machines. The majority of workers that have relatively high wages thereby tends to increase, whilst the conditions that hinder the integration of a great number of workers are created (...). As a consequence, solely a minority is a beneficiary of that. In such conditions, a limited expansion of the middle classes and of their consumption capacity appears as an element for combating and reaffirming modern capitalist sectors" (Santos, 2008, p. 191). Richard Sennet also points out some paradoxes in the so-called flexible systems, given that, in order to subject their operation to various people, the difficulty should be minimized, fixing thus an order pattern. Hence, being difficulty and flexibility opposite values, it could be possible to create the conditions for an uncritical and indifferent activity of the users (Sennet, 2012, pp. 82-83).
The creative (or creator) destruction, under the model proposed for companies by Schumpeter (1982), requires this continuous renewal and disposition from people/ workers to adapt to new functions, to the daily uncertainties, which represent, as Sennet (2012, p. 32) affirms, the singularity of this epoch: the instability intends to be normal and its dilemma lied in that universality.

Although not aiming at breaking through such question, this work seeks to meditate on the latent organizational possibilities brought by social and collaborative business, which propose a self-management, emancipatory and cooperative driven experience by the involved agents in the processes of preparing and producing goods and services.

\section{CREATIVE ECONOMY AS A PREFERENTIAL MARKET SEGMENT TO SOCIAL AND COLLABORATIVE BUSINESS}

As a consequence of being mainly organized upon intangible and, therefore, abundant resources, filled up with creativity, culture and experience, the Creative Economy is aligned with the proposals elaborated by social and collaborative business in terms of generating positive externalities.

In spite of the lack of international harmonization in regard to the encompassed segments, the Creative Economy and the industries that shape it are an output of the amalgam among creative arts, new technologies and the market potential brought by globalization. New technologies are charged with promoting the reunion between arts and science by the means of propagating knowledge and drafting alternatives to the production of goods, in a counterpoint for the oligopoly structures organized by the market and assured by the state. Globalization was given the role to expand market's potential and to surface the existing conflicts between culture producers and consumers. On its turn, the role of creative arts is recognized by the novelty they introduce (Reis, 2008, pp. 23-23).

The adaptations that are proposed to workers in regard to their functions also respond to the flexibility that is expected from companies in attention to new social demands. The social claim for the adjustment of companies to a new role, in which values like the reduction of environmental damages (and possible compensations to the generated negative externalities), includes the offering of better conditions to workers, so as to allow the workplace to be an environment for exercising citizenship and dignity. Beyond that, the use of technologies is fundamental for the development of social business: due to 
the ubiquitous and non-rival characters of goods that are intense on information, there is a great possibility that the shared use of such goods, beyond representing a disruption of the ownership logic, is anchored on rights over these scarce goods. In this sense, Sennet's understanding of "man, creator of himself" (2013) is endorsed by granting to work the necessary centrality to life's constitution and to overcome to the dichotomy between craftwork and intellectual tasks.

In Brazil, the mapping of the creative industries promoted by Industrial Federation of Rio de Janeiro (Federação das Indústrias do Estado do Rio de Janeiro - FIRJAN, 2016), released in 2016, categorized creative industries in four big areas: Consumption, Culture, Media and Technology. On their turn, these would cover thirteen subareas. Consumption would include advertising, architecture, design and fashion; in Culture, there would be cultural expressions, such as handcraft, folklore and gastronomy, patrimony and arts, and music and dramatic arts; Media would include the publishing (digital content also) and audiovisual market (content development, distribution, programming and transmission); and Technology would be divided into R\&D (experimental development in research on all areas, except for biology), biotechnology (research on biology and bioengineering), and ITC (Information Technology and Computing). The thirteen subareas, or "creative segments", are basically the same that had already been listed in the Mapping of the Creative Industries released by such Federation in 2012 and 2014 (FIRJAN, 2012; 2014). United Nations Conference on Trade and Development (UNCTAD), in a report from 2010, also presented a categorization for the Creative Economy, affirming that it represents an enormous potential for the so-called "feasible development". An important feature of the said document is the mapping of the productive chain of goods and services that accompany these segments. For the purposes of this research, the interest provoked by the Creative Economy is grounded on the generation of their aggregated values, publicized by the statistics concerning economic impact. According to UNCTAD, between 2000 and 2005, creative products and services grew by $8.7 \%$ per year.

In accordance with FIRJAN, in 2013, 251 thousand companies represented the creative industry in Brazil, pointing to a growth of $69.1 \%$ in the sector in the last decade (in 2004, there were 148 thousand companies). In regard to formal jobs, the creative industry employs 892.5 thousand formal workers in the country, and the creative industry is responsible for $2.6 \%$ of the GDP (or 126 billion Brazilian Reais) in 2013 and 2.1\% in 2014 (FIRJAN, 2014). The rapid growth of the sector, along the last 10 years, was of 69\% (Planeta Sustentável, 2015).
It means that there is a huge potential brought by the creative industries for the production of wealth and jobs, beyond representing a way of expression and manifestation of an "own" culture, increasingly more amenable to being given airtime and being propagated without the former necessary adaptations and preset formats. As Santos (2007) has affirmed, despite the geometric proliferation of the number of radio broadcasters and TV stations in certain countries, the capacity of producing programs was, nonetheless, limited due to their high costs. The reduction of costs and the propagation of information technologies gain, thus, an extra dimension: beyond being an important way of producing goods, they appear as an economic and cultural potential for classes that would have less conditions for producing goods or imparting their ways of life ${ }^{6}$.

As pointed by Lafer (1995, pp. 34-37), the culture policy - which is distinct from cultural policy ${ }^{7}$ - represents a strategic institution for freedom, which manifests: 1) under freedom as no impediment: manifested into a free culture, not hindered by obstacles of material order "that embarrass the free flow and exchange of ideas, or by psych and moral barriers that result in pressure of several kinds over consciousness and minds of citizenship"; 2) under freedom as participation, which is represented by the "broadening of opportunities for citizen collective participation in the creation and propagation of cultural

6 Nigerian movies industry is a great example, Nollywood, as it is known, produces more than 50 titles per week; 2,600 per year - twice the Indian industry (Bollywood) and four times more than Hollywood. Movies are an output of simple, homemade productions, most of the times done with cellphone cameras: a Nigerian movie costs US\$20 thousand on average. The prolific Nigerian movies industry has millions of spectators all over the African continent, despite its linguistic and ethnic diversity, and it has been increasingly exporting its products outside the continent, at least to the African world that exists outside Africa (Axt et Versignassi, 2011). In this regard, Carlo Ginzburg, talking about what he calls subordinate and dominant cultures, poses the question: would there be a hierarchical relationship between them or do they express alternative content? Would there be circularity between the "two levels of culture?" "The employment of the term culture to define a set of attitudes, beliefs, and behavioral codes that are proper of the subordinate classes in certain periods is relatively late and it was borrowed from cultural anthropology. Solely through the concept of 'primitive culture' we reached the recognition that such individual, who was once defined under a paternalist manner as 'bottom layers of civilized people', had culture" (Ginzburg, 1976, pp. 1617).

7 Lafer understands "culture policy" as the one founded on political interests that aim at the hegemonic domination by the State, imposing its views on society and law. 
Brazilian Journal of Operations \& Production Management

Volume 15, Número 3, 2018, pp. 453-460

DOI: 10.14488/BJOPM.2018.v15.n3.a13 goods"; and 3) under freedom as bildung (cultural formation lato sensu), "as the unfoldment of the human potential through the autonomous construction and ripening of the personality of each individual. Lafer affirms that second generation rights ${ }^{8}$ (among social, economic, and cultural ones) inscribe the need of freedom as participation and thus reinforce freedom as non-impediment - where we would add freedom as bildung ${ }^{9}$, in the same sense of the construction of substantive liberties of Sen (2012). Continuing, Lafer highlights the relevance of such rights by affirming a liberal view on equality "that is not equal to egalitarianism, which considers it to be desirable that everyone is equal in everything, but, instead, that the equality of opportunities is enlarged, so that everyone may freely seek a differentiated identity" (Lafer, 1995, p. 37).

The conception of cultural goods presupposes the recognition of distinct cultural manifestations, under an insubordinate manner: the creation, innovation and uniqueness are essential components of the recognition of such goods as products and services that carry value with themselves. New technological instruments enable them to be materialized, as well as the recognition of a creative industry allows their insertion and valuation in the market. However, these goods, due to their own characteristics, such as ubiquity and non-rivalry, present a price formation that is distinct from the traditional model, based on production costs, which is the main reason why they require new organizational practices, where social and collaborative business are embedded.

Porter (2001, p. 66) raises an important question on the use of new technologies for data sharing: as they extraordinarily ease the access to potential buyers to information goods, the capture of profits by (traditional) companies may be, very often, hampered. That is, when tacit knowledge becomes explicit, there is risk of jeopardizing property (intellectual property and goods and services that it enables to be produced $)^{10}$. Therefore, the

8 "First generation rights, such as freedom of religion, thinking and opinion (we hereby highlight professional association), by assuring the breadth of the lawful sphere, giving rise to freedom as no impediment" (Lafer, 2005, p. 37, emphasis added).

9 The protection of freedom from and freedom to are construed as conditions that enable a differentiated, pluralist freedom as building, which is a key value for liberalism (Lafer, 1995, p. 37).

10 Tacit knowledge would be the least codified one (of a more difficult obtainment or reading, such as human experiences, know-how, and everything else that depends on a cultural background) and, therefore, of a more difficult transfer, whilst explicit knowledge appears to be the most codified one, and whose transfer is made through easier ways. The tacit, complex knowledge may become more explicit inasmuch as partners de- management of the productive chain becomes extremely important for the reduction of transaction costs, which economically justifies the existence of the company and of the network of interconnected companies, tending to reverberate of goods of greater quality ${ }^{11}$.

The productive sequence of a good, as from its conception, production in strict sense, and commercialization is thereby frequently inverted. Flexible production and just in time bring up the "productive character of consumption", that is, the "consumed" as a potent producer of cognitive data that is necessary to a micro-regulation of the production, which is very close to an ideal simultaneity that is capable of getting rid of wastes and idle activities that may be construed as inefficient. And it is, above all, the access to new technologies and information that turns the user of these technical apparatuses into innovation co-producers. In the so-called cognitive capitalism (Moulier-Boutang, 2009), positive externalities would be generated by the cooperation in knowledge networks, through "work outside worktime, (...) [by] the implicit knowledge" in which the capacity of contextualization is transformed and reveals itself in desired products and services. In this sense, the author proposes a new categorization of three kinds of inputs for the production of goods and services: hardware, software and wetware (the component of the individual's experiences). The use of Business Intelligence (BI), a term that is used to refer to the set of theories, methodologies, structures, and technologies that transform the great amount of raw data into useful information for strategic decision making, is particularly interesting in this context (Universidade de Coimbra, 2015).

Hence, social and collaborative business could strengthen the demiurge potential of the Creative Economy, bearing in mind that they are new organizational modalities rooted on another paradigm of profitability and generation of positive externalities, also through sharing and the intersection between production and consumption instances.

velop a "broader band of communication". Economically, when knowledge appears to be under a very tacit way, the difficulty of transferring and implementing the technology is high, gains are uncertain and the process is costly, so that only those who possess the appropriate technology are able to take economical advantage on it. When knowledge is highly codified, the value of information is low, just like its transfer, and exactly due to such penetration, more players are able to produce a certain good (Fagerberg et Mowery, 2009).

11 It is necessary to except that the quality of the goods, as well as the own notion of cultural goods and the concept of culture (mass included), deserve more considerations, which are limited in this paper due to its scope. 


\section{FINAL REMARKS}

The division of labor model from the notorious description made by Adam Smith over the handicraft of pinholes, utterly enhanced by Taylorism/Fordism, and which would work as basis for the political economy of the XX century is at stake. We are witnessing a subversion of the productive sequences of some goods and services upon certain questions such as: outsourcing, the reduction of complex works in relation to simple works due to access to and lower costs of technologies, and the consequent reduction of the split between handling execution and intellectual labor. Alongside, the fact that function specialization, due to the market's dimension, has its importance diminished in a universe of small scale production of a "variety economy" sold by the cult of entrepreneurship and corporate social responsibility. This increasing complexity of markets requires greater resources to learning economies - what brings man to the core of the productive process and turns him into the main asset of the business. Therefore, a plurality of inputs reorganizes the traditional sharing lines between capital and labor and between qualified and non-qualified labor; the use of expressions of human or intellectual capital is, on its turn, symptomatic of such process.

Further to this characteristic, one should add the increase of models for cooperation and the organization in networks, enabled by IT, which allow a rise in the "cooperation among knowledges" and embark the decline of a limited paradigm over the use of productive resources and an enlargement of goods and services that carry value.

New techniques, as the special process of data digitization and storage, and exchanges provided by the internet have promoted true revolutions in the way under which goods and services are traded. This overwhelmingly shifts the structure of companies that explores these services that are intense in terms of information. It means that new technologies and the web environment represent a space for opportunities to entrepreneurs, imposing, at the same time, the necessity to think of how these goods and services may be monetized. Hence, recognizing the value of cultural and informational goods requests the construction (or discovery) of new markets for them: the democratization of the means of production - and consumption - is really important in order to think about the issue of the creative industry and the organization of social and collaborative business.

Therefore, the immaterial feature of the produced goods enables a broad relearning in regard to their conditions of use and exclusive appropriation. The ways under which these goods circulate in a company (and in society as a whole) enable a great inquiry over the notion of public good, intellectual property and, consequently, over the vertical way of production. It is thereby understood that social and collaborative business work for this purpose of endogenous growth and better division of wealth in the insofar as their own structure is rooted on sharing, distribution and co-production of material and immaterial goods.

\section{REFERENCES}

Boltanski, L.; Chiapello, È. (2009), O novo espírito do capitalismo, WMF Martins Fontes, São Paulo, SP.

Castells, M. (2013), Redes de indignação e esperança: Movimentos sociais na era da internet, Zahar, Rio de Janeiro, RJ.

Coase, R. (1937), "The Nature of the Firm", Economica, Vol. 4, No. 16, pp. 386-405.

Universidade de Coimbra (2015), Business Intelligence Database.

Federação das Indústrias do Estado do Rio de Janeiro - FIRJAN (2012), "Mapeamento da Indústria Criativa no Brasil", FIRJAN, Rio de Janeiro, RJ.

Federação das Indústrias do Estado do Rio de Janeiro - FIRJAN (2014), "Mapeamento da Indústria Criativa no Brasil", FIRJAN, Rio de Janeiro, RJ.

Federação das Indústrias do Estado do Rio de Janeiro - FIRJAN (2016), "Mapeamento da Indústria Criativa no Brasil", FIRJAN, Rio de Janeiro, RJ.

Ginzburg, C. (1976), O queijo e os Vermes, 2nd ed., Companhia das Letras, São Paulo, SP.

Gurisatti, P. (1999), “O nordeste italiano: nascimento de um novo modelo de organização industrial", in: Coco, G.; Galvão, A. P.; Urani, A. (Ed.), Empresários e empregos: o caso da terceira Itália, DP\&A, Rio de Janeiro, RJ, pp. 7799.

Lafer, C. (1995), Desafios: Ética e Política, Siciliano, São Paulo, SP.

Fagerberg, J.; Mowery, D. C. (Ed.) (2009), "The Oxford Handbook of Innovation", Oxford University Press, available from: http://www.oxfordhandbooks.com/oso/public/ content/oho_business/9780199286805/toc.html (accessed 2018 Jul 31).

Nunes, R. D. et al. (2009), “A experiência sócio-técnica no ambiente de produção: uma discussão acerca do Volvismo", Revista de Administração UFSM, Vol. 2, No. 2, pp. 235-49.

Planeta Sustentável (2015), “Economia não precisa ser chata e pode salvar o planeta", available from: planeta- 
sustentavel.abril.com.br/noticia/atitude/economia-nao-precisa-ser-chata-e-pode-salvar-o-planeta-criativa-cricular-colaborativa-857323.shtml?func=2 (accessed $2018 \mathrm{Jul}$ 31)

Porter, M. (2001), "Strategy and the Internet", Harvard Business Review, No. 3, pp. 62-78.

Reis, A. C. (2008), Economia Criativa como estratégia de desenvolvimento: uma visão dos países em desenvolvimento, Itaú Cultural , São Paulo, SP.

Santos, M. (2007), O espaço do cidadão, Edusp, São Paulo, SP.

Santos, M. (2008), O espaço dividido, Edusp, São Paulo, SP.

Schumpeter, J. A. (1982), Teoria do desenvolvimento econômico: uma investigação sobre lucros, capital, crédito, juro e o ciclo econômico, Abril Cultural, São Paulo, SP.

Sen, A. (2012), Desenvolvimento como liberdade, Record, Rio de Janeiro, RJ.
Sennett, R. (2012), A corrosão do caráter: as consequências pessoais do trabalho no novo capitalismo, Record, Rio de Janeiro, RJ.

Sennett, R. (2013), O Artífice, Record, São Paulo, SP.

United Nations Conference on Trade and Development - UNCTAD (2015), "Culture for Development Indicators (CDIS)", available from: <http://en.unesco.org/creativity/ cdis/> (accessed 2018 Jul 31).

Wood Junior, T. (1992), “Fordismo, Toyotismo e Volvismo: os caminhos da indústria em busca do tempo perdido", Revista de Administração de Empresas, Vol. 32, No. 04., pp. 6-18.

Yunus, M. (2010), Criando um negócio social, Campus-Elsevier, Rio de Janeiro, RJ.

Yunus Negócios Sociais Brasil (2017), "Quem somos", available from: <http://www.yunusnegociossociais. com/\#!quem-somos/c3me> (accessed 2018 Jul 31).

Received: 07 Mar 2018

Approved: 25 Jul 2018

DOI: 10.14488/BJOPM.2018.v15.n3.a13

How to cite: Stephan, C. (2018), "Social and Collaborative Businesses: approaches and potential brought by the Creative Economy", Brazilian Journal of Operations \& Production Management, Vol. 15, No. 3, pp. 453-460, available from: https://bjopm.emnuvens.com.br/bjopm/article/view/465 (access year month day). 